\section{EFEKTIFITAS JAKSA PENGACARA NEGARA DALAM UPAYA PEMULIHAN KEUANGAN NEGARA/DAERAH SEBAGAI AKIBAT TINDAK PIDANA KORUPSI DI KEJAKSAAN NEGERI PURWOKERTO Oleh: Sutrisno ${ }^{124}$}

\begin{abstract}
Based on the result of the research and a discussion to the main problem that proposed, therefore we can make some conclusion: The effectivity of State attorney On The Refund of State/Region Monetary Due To Corruption Act In The State Attorney Office Purwokerto, which purpose is to return the loss of state fund or state economy due to corruption act, if we review it from the effectivity of State attorney as one of the state instrument to return the state/region economy as a result of corruption act by using UU No 3 Tahun 1971 about Eradication of Corruption Act In The State Attorney Office Purwokerto, we can say that it hasn't effective yet, due to Litigation process handled by State attorney which filed civil action to the District Court, no one is capable to pay the loss of state/region due to corruption act in civil ruling, because the defendent already has no possession. Then, on Non Litigation way, using State attorney instrument, a little bit effective even though has to pay replacement money by credit because the defendant is capable to pay off the replacement. If we use UU No 31 Tahun 1999 that has been changed and replaced to UU No 20 Tahun 2001 about the Changes on UU No 31 Tahun 1999 about Erradication of Corruption Act to a State Attorney, it won't be a problem because if the defendant is not capable of paying the replacement money based on the decision, the defendant will undergo the subsidiary criminal in the form of penalty, which is the period of time will not exceed the main criminal threat dan the period of time has already decided on the decision.

That factors become obstacles, is the State Attorney will not able to perform a sequest sizing because the defendant is unable and has no possession in a nominal of money being corrupted, then from the Law enforcer itself, that the State Attorney is having difficulties to track posession that belongs to the defendant which is gain from the corruption act or assume gained from the corruption act, while the obstacles from the society, there is a lack of awareness from the society itself, which is a lack of concern to give information earlier and detail on the possession belong to the defendant to the law enforcer to a person a suspected as a corruption perpetrators.

Keyword: to Recover, State/Region monetary, criminal act
\end{abstract}

\begin{abstract}
ABSTRAK
Efektifitas Jaksa Pengacara Negara Dalam Upaya Pengembalian Keuangan Negara/Daerah Akibat tindak Pidana Korupsi di Kejaksaan Negeri Purwokerto, tujuannya adalah sedapat mungkin untuk dapat mengembalikan kerugian keuangan negara atau perekonomian Negara akibat tindak pidana korupsi, jika ditinjau dari efektifitas Jaksa Pengacara Negara sebagai salah satu instrumen negara untuk mengembalikan perekonomian negara/daerah akibat tindak pidana korupsi dengan menggunakan UU No. 3 tahun 1971 tentang Pemberantasan Tindak Pidana Korupsi. Dikatakan efektif apabila

${ }^{124}$ Kejaksaan Tinggi, Daerah Istimewa Yogjakarta. HP. 0812158968
\end{abstract}


1133 | Jurnal Idea Hukum

Vol. 4 No. 2 Oktober 2018

Magister Hukum Fakultas Hukum Universitas Jenderal Soedirman

Jaksa Pengacara Negara menggunakan dengan cara Non Litigasi walaupun penyelesaiannya belum optimal karena Terpidana membayarnya dengan cara mengangsur. Dibandingkan dengan cara Litigasi, proses Litigasi yang ditangani Jaksa Pengacara Negara dengan mengajukan gugatan perdata ke Pengadilan Negeri walaupun gugatannya dimenangkan Jaksa Pengacara Negara akan tetapi tidak ada yang mampu membayar kerugian negara/daerah akibat tindak pidana korupsi dalam putusan perdatanya, karena tergugat sudah tidak mempunyai harta benda yang cukup sehingga eksekusinya tidak bisa dilaksanakan. Sedangkan jika menggunakan UU No.31 tahun 1999 yang telah dirubah dan diganti dengan UU No.20 tahun 2001 tentang Perubahan UU No.31 tahun 1999 tentang Pemberantasan Tindak Pidana Korupsi bagi Jaksa Pengacara Negara tidak menjadi masalah karena apabila Terpidana tidak mampu membayar Uang Pengganti sesuai dengan putusannya maka Terpidana akan menjalani pidana subsidernya berupa pidana penjara yang lamanya tidak melebihi ancaman pidana pokoknya dan lamanya sudah ditentukan dalam putusan.

Faktor-faktor yang menjadi kendala Jaksa Pengacara Negara Dalam Upaya Pengembalian Keuangan Negara/Daerah Akibat tindak Pidana Korupsi di Kejaksaan Negeri Purwokerto, yaitu: Ada beberapa kondisi lain yang menghambat diantaranya: tempat tingal Terpidana yang tidak diktahui secara pasti sehingga menyulitkan Jaksa Peangacara Negara dalam melakukan upaya pemulihan keuangan Negara/daerah baik secara Non Litigasi maupun Litigasi serta kurang kesadaran masyarakat untuk melaporkan adanya tindak pidana korupsi dilingkungannya serta tidak adanya kesadaran masyarakat untuk melaporkan harta benda yang dimiliki Terpidana yang merupakan hasil dari tindak pidana korupsi.

Kata kunci: pemulihan, keuangan Negara/Daerah, tindak pidana 


\section{A. Pendahuluan}

Sebagaimana diketahui bahwa Tindak Pidana Korupsi di Indonesia menjadi masalah yang sudah meluas di masyarakat, perkembangannya terus meningkat dari tahun ke tahun baik dari kuantitas perkara yang terjadi dan kuantitas kerugian keuangan Negara maupun dari segi kualitas Tindak Pidana yang dilakukan semakin sistematis serta lingkupnya yang memasuki aspek kehidupan masyarakat.

Upaya pemberantasan tindak pidana korupsi yang dilakukan oleh pemerintah sampai saat ini masih terus bergulir dengan berbagai strategi, tetapi perbuatan korupsi masih tetap saja merebak di berbagai sektor kehidupan, tidak saja di birokrasi termasuk BUMN, sehingga oleh sebagian kalangan korupsi dipandang sebagai kejahatan yang luar biasa atau extra ordinary crime karena selain merugikan keuangan nagara juga merupakan pelanggaran terhadap hak-hak sosial dan ekonomi masyarakat luas ${ }^{125}$.

Metode penegakan hukum secara luar biasa dalam upaya pemberantasan tindak pidana korupsipun telah dilakukan secara optimal, intensif, proporsional dan profesional serta

\begin{tabular}{ccc}
\hline 125 & Marwan Effendy, & Sistem \\
Peradilan & Pidana Tinjauan & Terhadap \\
Beberapa Perkembangan Hukum & Hukn \\
Pidana, Referensi,Tahun 2012, hlm.132.
\end{tabular}

berkesinambungan. Namun tingginya jumlah angka korupsi, jika dibandingkan dengan beberapa Negara lain di dunia, kita masih menempati urutan yang cukup memprihatinkan, memalukan, yang acapkali menjadi focus perbincangan dikalangan kalayak ramai. Pemerintah dalam upaya pemberantasan korupsi dari berbagai perspektif aparat penegak hukum (Kepolisian, KPK dan Kejaksaan dan instansi terkait lainnya, seperti BPK, BPKP, PPATK, Kalangan Ahli/Akademisi, OJK, Imigrasi, Ditjen Pajak, Kepabeanan/Cukai dan Lembaga Pemasyarakatan/Rutan) cukup sedemikian gencar dilakukan penegakan dan penindakan penanganan dan penyelesaian perkara tindak pidana korupsi melalui mekanisme penerapan peraturan perundang-undangan yang ada dan berlaku $^{126}$.

Meningkatnya Tindak Pidana Korupsi jelas akan membawa bencana tidak saja terhadap kehidupan perekonomian nasional tetapi juga pada kehidupan berbangsa dan bernegara pada umumnya. Tindak Pidana Korupi yang meluas dan sistematis juga merupakan pelanggaran terhadap hakhak soial dan hak-hak ekonomi masyarakat, dan karena itu semua,

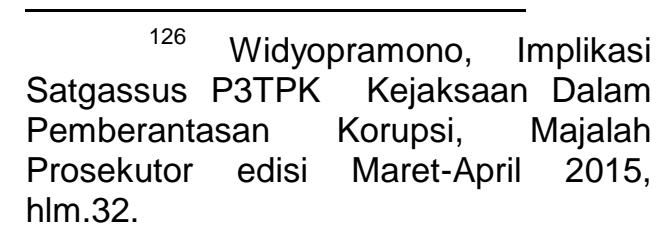


maka Tindak Pidana Korupsi tidak lagi digolongkan sebagai kejahatan biasa melainkan telah menjadi suatu kejahatan yang luar biasa (extra ordinary crimes).

Upaya penegakan hukum dalam memberantas Tindak Pidana Korupsi yang dilakukan secara konvensional selama ini mengalami berbagai hambatan, untuk itu diperlukan metode penegakan hukum yang luar biasa dalam upaya pemberantasan Tindak Pidana Korupsi yang pelaksanaannya dilakukan secara optimal, intensif, profesional serta keseimbangan.

Menurut Deputi Pemberantasan Pusat Pelaporan dan Analisis Transaksi Keuangan (PPATK) Wizral Yanuar, ada beberapa hal yang membuat korupsi sulit dihilangkan di Indonesia ${ }^{127}$ :

1. Pertama, korupsi adalah kejahatan yang terorganisir dan melibatkan aparat.

2. Korupsi merupakan rantai kejahatan yang panjang, akibatnya sulit untuk mencari alat bukti guna mengusut atau menuntaskan kasus korupsi.

3. Selain itu Locus delicti (tempat dan lokasi kejadian) dalam kasus korupsi terkadang bersifat lintas Negara. Apalagi alat atau

127

http://rubik.okezone.com/read/10538/ber antas korupsi dengan strategi follow-themoney sarana kejahatan semakin canggih.

4. Selain itu sulitnya memberantas korupsi juga disebabkan adanya persepsi dari masyarakat Indonesia dalam memandang korupsi.

5. Kasus korupsi di Indonsia sangat sulit untuk diungkap juga karena kasus korupsi itu terkadang melibatkan banyak pihak dan berbelit.

Masih menurut Wizral Yanuar ${ }^{128}$, korupsi di Indonesia ibarat gunung es, hanya kelihatan atasnya saja. Apa yang salah di republik ini? semakin dibongkar korupsi ini semakin banyak korupsi dilakukan, karena adanya empat unsur, antara lain: niat untuk melakukan, kemampuan untuk melakukan, peluang atau kesempatan dan target yang cocok.

Pemerintah khususnya aparatur penegak hukum, harus menjalankan proses penegakan hukum dengan tegas, konsisten dan terpadu agar mampu menghasilkan penegakan hukum yang berkeadilan, memberikan kepastian hukum yang demikian diharapkan dapat meningkatkan kepercayaan masyarakat, menimbulkan efek jera, mencegah calon koruptor, mengoptimalkan pengembalian uang negara/rakyat serta dampak positif

128 Ibid 
lainnya ${ }^{129}$. Serta yang lebih penting lagi dalam upaya pencegahan dan pemberantasan Tindak Pidana Korupsi perlu semakin ditingkatkan dan diintensifkan dengan tetap menjunjung tinggi hak asasi manusia dan kepentingan masyarakat.

Penegakan hukum terhadap pemberantasan Tindak Pidana Korupsi seharusnya dapat memenuhi dua tujuan yakni:

1. Agar pelaku Tindak Pidana Korupsi dapat dihukum (dipidana) yang setimpal sesuai dengan perbuatnnya.

2. Agar kerugian negara atau perekonomian negara yang diakibatkan dari Tindak Pidana Korupi itu dapat dikembalikan.

Persoalan pengembalian kerugian Negara (asset recovery) dalam praktek penanganan pekara korupsi telah menjadi persoalan serius, sebab berdasarkan beberapa fakta banyak perkara korupsi yang pelakunya telah dijatuhi pidana namun dalam hal pelaksanaan pidana uang Pengganti sulit untuk terwujud dan ternyata pelaksanaan pidana Uang Pengganti tidak semudah yang dibayangkan.

Dalam praktek terhadap kasuskasus yang menggunakan instrument

$129 \quad$ Bambang Waluyo,
Penegakan Hukum di Indonesia, Penerbit PT.Sinar Grafika, Tahun 2016, hlm.61.
Undang-Undang Nomor 3 tahun 1971 tersebut untuk pidana pembayaran Uang Pengganti apabila Terpidananya tidak mampu membayar maka Jaksa selaku eksekutor penyelesaiannya menggunakan sarana hukum perdata yakni Jaksa selaku Jaksa Pengacara Negara (JPN) akan melakukan gugatan perdata terhadap Terpidana. Hal ini sesuai dengan Pasal 30 ayat (2) UU Nomor 16 tahun 2004 tentang Kejaksaan Republik Indonesia yang menyebutkan bahwa di bidang Perdata dan Tata Usaha Negara, Kejaksaan dengan Kuasa Khusus dapat bertindak baik di dalam maupun di luar pengadilan untuk dan atas nama negara atau pemerintah.

Dalam Undang-Undang Nomor 31 tahun 1999 sebagaimana yang telah dirubah dengan Undang-Undang Nomor 20 tahun 2001 tentang Pemberantasan Tindak Pidana Korupsi terhadap pidana Uang Pengganti ini sedikit mengalami perubahan. Dalam Pasal 18 ayat (2) disebutkan bahwa Jika Terpidana tidak membayar uang pengganti sebagaimana dimaksud dalam ayat (1) huruf $b$ paling lama dalam waktu 1 (satu) bulan sesudah putusan pengadilan yang telah memperoleh kekuatan hukum tetap, maka harta bendanya dapat disita oleh Jaksa dan dilelang untuk menutupi uang pengganti tersebut. Kemudian dalam pasal 18 ayat (3) dijelaskan dalam hal Terpidana tidak memiliki harta benda yang mencukupi 
1137 | Jurnal Idea Hukum

Vol. 4 No. 2 Oktober 2018

Magister Hukum Fakultas Hukum Universitas Jenderal Soedirman

untuk membayar uang pengganti sebagaimana dimaksud dalam ayat (1) huruf $b$, maka dipidana dengan pidana penjara yang lamanya tidak melebihi ancaman maksimum dari pidana pokoknya sesuai dengan ketentuan dalam Undang-undang ini dan lamanya pidana tersebut sudah ditentuklan dalam putusan pengadilan.

Kendala pelaksanaan pidana
Uang Pengganti tentu akan
menimbulkan konsekuensi terhadap
tujuan dari penegakan dan
pemberantasan tindak pidana korupsi itu
sendiri sebab penegakan dan
pemberantasan tindak pidana korupsi
tidak semata-mata terletak pada
dipidananya pelaku saja tetapi yang
lebih penting dan utama adalah
bagaimana kerugian keuangan Negara
dapat dikembalikan.

Berkaitan dengan pemulihan atau pengembalian keuangan negara sebagai akibat dari Tindak Pidana Korupsi tersebut maka Kejaksaan sebagai satu-satunya alat pemerintah dalam bidang penuntutan juga mempunyai kewenangan untuk bertindak dalam hal pengembalian keuangan Negara sebagai akibat dari perbuatan korupsi dan hal ini dipertegas dalam Undang-Undang Nomor 16 Tahun 2004 tentang Kejaksaan Republik Indonesia pasal 30 ayat (2) yang menyatakan:
Dibidang Perdata dan Tata Usaha Negara, Kejaksaan dengan kuasa khusus dapat bertindak baik didalam maupun diluar Pengadilan untuk dan atas nama Negara atau pemerintah.

Bahwa di Kejaksaan Negeri Purwokerto antara tahun 2010 sampai 2011 terdapat data penyelesaian pemulihan keuangan Negara atau daerah sebagai akibat Tindak Pidana Korupsi baik melalui Litigasi maupun Non Litigasi.

\section{B. Perumusan Masalah:}

Berdasarkan uraian diatas penulis mencoba mengidentifikasi permasalahan sebagai berikut:

a. Bagaimanakah Efektifitas Jaksa Pengacara Negara (JPN) dalam upaya pemulihan keuangan Negara/Daerah sebagai akibat Tindak Pidana Korupsi di Kejaksaan Negeri Purwokerto?

b. Hambatan-hambatan apa yang saja yang dialami Jaksa Pengacara Negara (JPN) pada Kejaksaan Negeri Purwokerto dalam melakukan upaya pemulihan keuangan Negara/Daerah sebagai akibat Tindak Pidana Korupsi di Kejaksaan Negeri Purwokerto?

\section{Metode Penelitian}


Metode Pendekatan yang digunakan adalah Yuridis Sosiologis, pendekatan yang memandang hukum sebagai suatu fenomena yang dalam interaksinya tidak terlepas dari faktorfaktor non hukum. ${ }^{130}$ Spesifikasi penelitian deskriptif analitis. Data yang dipakai data primer yakni data yang diperoleh secara langsung dari masyarakat (perilakunya, data empiris) ${ }^{131}$. Data Sekunder diperoleh dari bahan pustaka, yang terdiri dari bahan hukum primer, ${ }^{132}$ bahan hukum sekunder dan analisis data secara kualitatif.

D. Hasil

\section{Penelitian}

dan

Pembahasan.

1. Efektifitas Jaksa Pengacara Negara Dalam Upaya Pemulihan Keuangan Negara/Daerah Sebagai Akibat Tindak Pidana Korupsi di Kejaksaan Negeri Purwokerto.

Sehubungan dengan masalah Upaya Pemulihan Keuangan Negara/Daerah sebagai akibat tindak pidana korupsi yang dilakukan Jaksa Pengacara Negera pada Kejakssaan Negeri Purwokerto, berdasarkan hasil penelitian data sekunder di Kejaksaan Negeri

\footnotetext{
${ }^{130}$.Ronny Hanitijo Saoemitro, Metodologi Penelitian Hukum, Ghalia Indonesia, Jakarta,Tahun 1992, hlm.11.

${ }^{131}$.Soerjono Soekanto, Pengantar Penelitian Hukum, Penerbit Universitas Indonesia, Tahun 1984, hlm.51.

${ }_{132}$.Loc. cit.
}

\begin{abstract}
Purwokerto didapati beberapa putusan Pengadilan dalam perkara tindak pidana korupsi.
\end{abstract}

Menurut Roscoe Pound,
bahwa fungsi hukum adalah
sebagai a tool of social engineering
atau sebagai alat rekayasa sosial,
bahwa hukum merupakan salah
satu unsur dalam hidup masyarakat
yang harus memasukan kepentingan umum. ${ }^{133}$ Unsur-unsur dalam bekerjanya hukum dalam interaksinya tidak terlepas keterkaitannya dengan kekuatankekuatan sosial dan persona lainnya. Hal ini berarti bekerjanya hukum di dalam masyarakat dipengaruhi oleh faktor-faktor non hukum, seperti: ekonomi, politik, sosial, budaya, teknologi dan sebagainya serta manusianya itu sendiri sebagai aspek persona lainnya yang merupakan faktor penting dalam bekerjanya hukum di dalam masyarakat.

Dengan demikian dapat dikatakan bahwa hukum itu hanya akan dapat berjalan melalui manusia. Manusialah yang menciptakan hukum, akan tetapi untuk pelaksanaan dari pada hukum yang telah dibuat itu masih diperlukan campur tangan manusia pula. Apabila setiap orang tidak

133. Menguak Tabir Hukum, Candra Pratama, Jakarta, Tahun 1996, hlm.98. 
bersedia untuk melakukan perbuatan hukum, maka gagal pulalah peraturan yang telah dibuat itu dilaksanakan secara lengkap.

Berdasarkan hal tersebut diatas maka dapat disimpulkan bahwa peranan manusia di dalam bekerjanya hukum sangatlah dominan. Padahal dalam bekerjanya hukum terdapat perbedaan antara bagan-bagan formal bagi tingkah laku manusia yang dibuat oleh hukum dengan tingkah laku manusia yang serta merta. Sebagaimana yang dikatakan Van Apeldorn, bahwa dalam setiap pengorganisasian, manusia itu selalu cenderung didapati terjatuh diluar bagan organisasi yang telah tersusun. Bahwa perbuatan manusia itu sulit untuk didisiplinkan oleh ketentuanketentuan formal organisasi, menurutnya disebabkan oleh karena mereka diwajibkan tunduk pada bagan tersebut mempunyai latar belakang yang berbeda-beda, yang masing-masing memberikan beban pengaruhnya kepada manusia, sehingga ia senantiasa mempunyai tafsiran sendiri mengenai perbuatan-perbuatan apa yang semestinya dilkukan. Sebagai faktor-faktor yang mempengaruhi, oleh Van Apeldorn disebutkan, yakni : kepribadian, asal-usul sosial, kepentingan ekonomi, maupun keyakinan politik serta pandangan hidupnya. ${ }^{134}$

Di dalam perkembangan ilmu hukum pada umumnya dalam praktek sering timbul masalahmasalah yang menyangkut keberadaan kaidah hukum dan efektifitas kaidah-kaidah hukum dengan mengetengahkan efektifitas hukum. Artinya efektifitas hukum akan disoroti dari tujuan yang ingin dicapai. Efektifitas mengandung arti keefektifan (efectivences) pengaruh/efek keberhasilan, atau kemanjuran//kemujaraban. ${ }^{135}$

Sehingga dalam membahas masalah permasalahan efektifitas Jaksa Pengacara Negara dalam pemulihan keuangan Negara/Daerah sebagai akibat tindak pidana korupsi, maka didalamnya terkandung masalah seberapa jauh lembaga penegak hukum/Jaksa Pengacara Negara dan perangkat hukum yang ada selama ini cukup efektif atau berpengaruh atau berhasil guna dalam rangka pemulihan keuangan

${ }^{134}$.Satjipto Rahardjo, Hukum dan Perubahan Sosial, Suatu Tinjauan Teoritis serta Pengalaman-pengalaman di Indonesia, Alumni, Bandung,Tahun 1983, hlm.72.

135. Barda Nawawi Arif, Kapita Selekta Hukum Pidana,Citra Aditya Bakti, Bandung, Tahun 2003, hlm.85. 
Negara/daerah sebagai akibat tindak pidana korupsi.

\section{Selanjutnya Barda Nawawi}

Arif mengatakan bahwa jika membicarakan efektifitas hukum untuk menanggulangi kejahatan (korupsi) tentunya tidak terlepas dari penganalisaan terhadap karakteristik dan variabel yang terkait, yaitu karakteristik obyek/sasaran yang dituju dan karakteristik dari alat/sarana yang digunakan (perangkat hukum pidan). ${ }^{136}$ Sedangkan efektifitas hukum tidak dapat dilepaskan dari tipe-tipe penyelewengan atau delik yang ada dalam masyarakat. Tipetipe penyelewengan tersebut merupakan kategorisasi secara teoritis terhadap berbagai jenis penyelewengan yang terjadi di dalam suatu masyarakat. ${ }^{137}$

\section{Pemikiran} tentang penegakan hukum sangat erat kaitannya dengan pemikiran tentang efektifitas peraturan perundang-undangan atau hukum yang berlaku, yang berarti bahwa pemikiran-pemikiran itu biasanya diarahkan pada suatu kenyataan apakah hukum atau peraturan perundang-undangan yang ada benar-benar berlaku atau tidak.

${ }^{136}$. Loc.cit.

137 SoerjonoSoekanto, Op.cit, Tahun 1985, hlm.68.
Menurut

Lawrence

M.Friedman menyebutkan bahwa efektif tidaknya penegakan hukum akan sangat tergantung pada 3 (tiga) unsur yakni substansi hukum/legal substance (peraturan hukum itu sendiri), struktur hukum/legal structure (aparat penegak hukum) dan budaya hukum /legal culture (masyarakatnya). Ketiga faktor tersebut bersama-sama atau sendiri-sendiri akan mempengaruhi efektif tidaknya suatu hukum. ${ }^{138}$

a. Substansi hukum, adalah norma (aturan, keputusan) hasil dari produk hukum.

b. Struktur hukum diciptakan oleh sistem hukum yang mungkin untuk memberikan pelayanan dan penegakan hukum.

c. Budaya hukum, adalah ide, perilaku, keinginan, pendapat dan nilai-nilai yang berkaitan dengan hukum (positif/negatif).

Berikut uraian pendapat Lawrence M.Friedman tentang hal tersebut di atas:

a. Substansi hukum (legal subtansi).

${ }^{138}$. Lawrence M.Friedman, 2009, Sistem Hukum, Perspektif IImu Sosial (The Legal System A Social Science Perspective),NusaMedia,Bandung hlm.33 
1141 | Jurnal Idea Hukum

Vol. 4 No. 2 Oktober 2018

Magister Hukum Fakultas Hukum Universitas Jenderal Soedirman

Substansi hukum dapat dikatakan sebagai salah satu faktor yang memberikan kontribusi kasus korupsi yang besar. Kasus ini terjadi karena substansi hukum mudah diciptakan untuk korupsi. Cara sederhana, menjadikan norma hukum yang tidak jelas atau kabur. Substansi hukum yang tidak jelas bukan hanya mudah untuk melakukan korupsi, tetapi juga memberikan kesempatan yang luas untuk aparat penegak hukum untuk "frizzing" sesuai dengan masingmasing kepentingan.

b. Struktur hukum.

Strukttur hukum/pranata hukum,dalam teori Lawrence Meir Friedman hal ini disebut sebagai sistem struktural yang menentukan bisa atau tidaknya hukum itu dilaksanakan dengan baik. Struktur hukum berdasarkan UU Nomor 8 Tahun 1981 meliputi: Kepolisian, Kejaksaan, Pengadilan dan Badan Pelaksana Pidana (Lapas). Kewenangan penegak hukum dijamin oleh undang-undang sehingga dalam melaksanakan tugas dan tanggungjawabnya terkepas dari pengaruh kekuasaan pemerintah dan pengaruh-pengaruh lain. Namun dari teori tersebut banyak diselewengkan. Buktinya banyak penegak hukum yang korupsi dan jika ketahuan melakukan korupsi mereka dihukum sangat singkat. Penting untuk melakukan reformasi yang sangat mendasar untuk system pengadilan, tidak hanya reformasi kelembagaan atau mekanisme reformasi prosedural, tetapi juga tentang kepribadian dan kerja aparat pengadilan dan perilaku masyarakat hukum yang kurang optimal. Penegakan hukum progresif menjadi prioritas alternatif yang wajib digunakan untuk kasus korupsi seperti ini, karena penanggulangan kasus cenderung monoton sehingga Indonesia akan menjadi surga bagi koruptor. Dalam penegakan hukum progresif diperlukan penegak hukum yang memiliki integritas tinggi juga moralitas.

c. Budaya hukum.

Kultur hukum menurut Lawrence Meir Friedman ${ }^{139}$ adalah sikap manusia terhadap hukum dan sistem hukum-kepecayaan, nilai, pemikiran, serta harapannya. Kultur hukum adalah suasana pemikiran sosial dan kekuatan sosial yang menentukan bagaimana hukum digunakan, dihindari, atau disalahgunakan.

139 .lbid,hlm.8 
Budaya hukum erat kaitannya dengan kesadaran hukum masyarakat. Semakin tinggi kesadaran hukum masyarakat maka akan tercipta budaya hukum yang baik dan dapat merubah pola pikir masyarakat mengenai hukum selama ini. Secara sederhana, tingkat kepatuhan masyarakat terhadap hukum merupakan salah satu indikator berfungsinya hukum. Masyarakat Indonesia sendiri belum terlalu paham dan patuh dengan proses hukum yang ada. Pelaksanaan hukum di Indonesia pun belum tampak adil. Korupsi dijadikan sebuah perilaku hukum yang negative dan dilakukan terus menerus. Untuk mengubah budaya hukum kita harus selalu memahami tentang nilai-nilai, tradisi, kebiasaan, dan segala sikap dominan yang berlaku pada semua aspek hidup. Kita harus serius mencegah kasus korupsi negara, Komisi Pemberantasan Korupsi (KPK) sudah mulai memberi sampel dan juga menunjukan komitmen dalam pemberantasan korupsi jelas dan nyata.

Dalam Pasal 10 Kitab
Undang-Undang Hukum Pidana
(KUHP) dikatakan bahwa selain
pidana pokok, pidana lain yang
dapat dikenakan terhadap

Terpidana yaitu pidana tambahan, termasuk pidana tambahan yang dikenal dalam sistem pemidanaan di luar KUHP yaitu pembayaraan uang pengganti yang dikenakan terhadap Terpidana. Namun pidana tambahan berupa pembayaran uang pengganti ini hanya khusus dikenakan kepada pelaku tindak pidana korupsi dan hal ini merupakan kewajiban untuk mengembalikan kerugian yang diderita oleh korban sebagai akibat perbuatan pelaku.

Sehubungan dengan permasalahan tentang efektifitas Jaksa Pengacara Negara dalam pemulihan keuangan Negara/Daerah sebagai akibat tindak pidana korupsi di Kejaksan Negeri Purwokerto, dimana salah satu unsur tindak pidana korupsi adalah adanya kerugian keuangan Negara. Terhadap kerugian keuangan Negara tersebut, Pemerintah telah membuat Undang-Undang Korupsi, baik Undang-Undang Nomor 3 Tahun 1971 maupun Undang-Undang Nomor 31 Tahun 1999 yang telah dirubah dengan Undang-Undang Nomor 20 Tahun 2001 tentang Perubahan atas Undang-Undang Nomor 31 Tahun 1999 tentang Pemberantasan Tindak Pidana Korupsi, yang menetapkan kebijakan bahwa kerugian 
1143 | Jurnal Idea Hukum

Vol. 4 No. 2 Oktober 2018

Magister Hukum Fakultas Hukum Universitas Jenderal Soedirman

keuangan negara sebagai akibat

tindak pidana korupsi harus dikembalikan atau diganti oleh pelaku korupsi.

Dalam Undang-Undang
Nomor 3 tahun 1971 tentang
Pemberantasan Tindak Pidana
Korupsi mengenai pidana
pembayaran uang pengganti diatur
dalam Pasal 34, yang menyatakan :
"Selain ketentuan-ketentuan Pidana
yang dimaksud dalam KUHP maka
sebagai hukuman tambahan
adalah:

a. Perampasan barang-barang tetap maupun tak tetap yang berujud maupun yang tak berujud, dengan mana atau mengenai mana tindak pidana itu dilakukan atau yang seluruhnya atau sebagian diperolehnya dengan tindak pidana korupsi itu begitu pula harga lawan barang-barang yang menggantikan barangbarang itu, baik apakah barangbarang atau harga lawan itu kepunyaan siterhukum ataupun bukan.

b. Perampasan barang-barang tetap maupun tak tetap yang betujud maupun yang tak berujud yang termasuk perusahaan siterhukum, dimana tindak pidana korupsi itu dilakukan, begitu pula harga lawan barang-barang yang menggantikan barang-barang itu, baik apakah barang-barang atau harga lawan itu kepunyaan siterhukum ataupun bukan, akan tetapi tindak pidananya, bersangkutan dengan barangbarang yang dapat dirampas menurut ketentuan tersebut sub a pasal ini. c. Pembayaran uang pengganti yang jumlahnya sebanyakbanyaknya sama dengan harta benda yang diperoleh dari korupsi.

sedangkan dalam Undang-Undang

Nomor 31 tahun 1999 yang telah

dirubah dengan Undang-Undang

Nomor 20 Tahun 2001 tentang

Perubahan Undang-Undang Nomor

31 Tahun 1999 tentang

Pemberantasan Tindak Pidana

Korupsi terdapat dalam Pasal 18,

yang menyatakan :

(1) Selain pidana tambahan sebagaimana dimaksud dalam Kitab Undang-Undang Hukum Pidana,sebagai pidana tambahan adalah:

a. Perampasan barang bergerak yang berwujud atau yang tidak berwujud atau barang tidak bergerak yang digunakan untuk atau yang diperoleh dari tindak pidana korupsi, termasuk peusahaan milik terpidana dimana tindak pidana korupsi dilakukan,begitu pula dari barang yang menggantikan barangbarang tersebut.

b. Pembayaran uang pengganti yang jumlahnya sebanyakbanyaknya sama dengan harta benda yang diperoleh dari tindak pidana korupsi.

c. Penutupan seluruh atau sebagian perusahaan untuk waktu paling lama 1 (satu) tahun.

d. Pencabutan seluruh atau sebagian hak-hak tertentu 
atau penghapusan seluruh atau sebagian keuntungan tertentu, yang telah atau dapat diberikan oleh Pemerintah kepada terpidana.

(2) Jika terpidana tidak membayar uang pengganti sebagaimana dimaksud dalam ayat (1) huruf b paling lama dalam waktu 1 (satu) bulan sesudah putusan pengadilan yang telah memperoleh kekuatan hukum tetap, maka harta bendanya dapat disita oleh Jaksa dan dilelang untuk menutupi uang pengganti tersebut.

(3) Dalam hal terpidana tidak mempunyai harta benda yang mencukupi untuk membayar uang pengganti sebagaimana dimaksud dalam ayat (1) huruf $b$, maka dipidana dengan pidana penjara yang lamanya tidak melebihi ancaman maksimum dari pidana pokoknya sesuai dengan ketentuan dalam undang-undang ini dan lamanya pidana tersebut sudah ditentukan dalam putusan pengadilan.

Baik Undang-Undang Nomor

3 Tahun 1971 tentang

Pemberantasan Tindak Pidana

Korupsi maupun Undang-Undang

Nomor 31 Tahun 1999 yang telah dirubah dengan Undang-Undang

Nomor 20 Tahun 2001 tentang

Perubahan atas Undang-Undang

Nomor 31 Tahun 1999 tentang

Pemberantasan Tindak Pidana

Korupsi adalah dibentuk dengan

tujuan untuk menyelamatkan keuangan Negara serta

mewujudkan masyarakat adil dan makmur berdasarkan Pancasila dan Undang-Undang Dasar 1945, karena perbuatan para pelaku korupsi sudah menghambat pembangunan nasional dan menghambat petumbuhan dan kelangsungan pembangunan nasional.

Oleh Karena itu kehadiran Undang-Undang Nomor 3 Tahun 1971 tentang Pemberantasan Tindak Pidana Korupsi maupun Undang-Undang Nomor 31 Tahun 1999 yang telah dirubah dengan Undang-Undang Nomor 20 Tahun 2001 tentang Perubahan atas Undang-Undang Nomor 31 Tahun 1999 tentang Pemberantasan Tindak Pidana Korupsi dalam implimentasinya diharapkan mampu untuk mencegah terjadinya kerugian negara serta dapat mengawasi penyelenggaraan Negara agar tetap bersih dan berwibawa sebagaimana diamanatkan oleh Majelis Permusyawaratan Rakyat dalam Tap MPR RI NomorXI/MPR/1998.

Penegakan hukum sebagai bentuk konkrit penerapan hukum sangat mempengaruhi secara nyata perasaan hukum, kepuasan hukum, manfaat hukum, kebutuhan atau keadilan hukum secara 
1145 | Jurnal Idea Hukum

Vol. 4 No. 2 Oktober 2018

Magister Hukum Fakultas Hukum Universitas Jenderal Soedirman

individual atau sosial. Penegakan hukum tidak mungkin terlepas dari aturan hukum, pelaku lingkungan tempat terjadi proses penegakan hukum, maka tidak mungkin ada pemecahan persoalan penegakan hukum apabila hanya melirik kepada proses penegakan hukum, apalagi lebih terbatas pada penyelenggaraan peradilan. ${ }^{140}$

Melalui Undang-Undang Nomor 16 Tahun 2004 tentang Kejaksaan Republik Indonesia, maka Kejaksaan melalui instrument Perdata dapat melakukan penagihan uang pengganti sebagai akibat tindak pidana korupsi yang dilakukan oleh para pelaku korupsi dalam rangka upaya pemulihan keuangan

Negara/Daerah khususnya terhadap putusan perkara tindak pidana korupsi yang dijatuhi putusan dengan menggunakan Undang-Undang Nomor 3 Tahun 1971 tentang Pemberantasan Tindak Pidana Korupsi.

Dalam Pasal 30 ayat (2) Undang-Undang Nomor 16 tahun 2004 dinyatakan bahwa di bidang Perdata dan Tata Usaha Negara, Kejaksaan dengan kuasa khusus

${ }^{140}$.Bagir manan, Varia Peradilan, Majalah Hukum Tahun ke XX No.241 Nopember 2005, Tahun 2005. dapat bertindak baik di dalam maupun di luar pengadilan untuk dan atas nama Negara atau pemerintah dimana dalam pelaksanaannya apabila perkara Korupsi diputus berdasarkan UU Nomor 3 tahun 1971 dan dalam putusannya menyatakan adanya pembayaran uang pengganti kepada Terdakwa akan tetapi Terdakwa tidak mampu membayarnya sesuai dengan Peraturan Jaksa Agung Republik Indonesia Nomor: Per020/A/JA/07/2014 tanggal 22 Juli 2014 tentang Petunjuk Pelaksanaan Penyelesaian Uang Pengganti yang diputus Pengadilan berdasarkan Undang-Undang Nomor 3 Tahun 1971 tentang Pemberantasan Tindak Pidana Korupsi bahwa Jaksa Pengacara Negara dalam menyelesaikan pemulihan kerugian keuangan Negara/Daerah sebagai akibat tindak pidana korupsi dapat dilakukan secara Non Litigasi dan Litigasi.

$$
\text { Dalam Bab IV angka } 1
$$

Peraturan Jaksa Agung Republik Indonesia Nomor: Per020/A/JA/07/2014 tanggal 22 Juli 2014 tentang Petunjuk Pelaksanaan Penyelesaian Uang Pengganti yang diputus Pengadilan berdasarkan Undang-Undang 
Nomor 3 Tahun 1971 tentang

Pemberantasan Tindak Pidana

Korupsi disebutkan bahwa

penyelesaian uang pengganti secara Non Litigasi dilakukan oleh Jaksa Pengacara Negara dengan cara negosiasi atau musyawarah dengan terpidana/eks terpidana/ahli waris berdasarkan Surat Perintah dengan menggunakan Formulir PUP-8 atau SP-3 berdasarkan Keputusan Jaksa Agung Nomor : 157/A/JA/11/2012 tentang Administrasi Perkara Perdata dan Tata Usaha Negara.

\section{Sedangkan penyelesaian} secara Litigasi sesuai Bab $\vee$ angka 1 berdasarkan peraturan yang sama dikatakan bahwa apabila secara non litigasi tidak dapat diselesaikan dalam jangka waktu yang sudah ditentukan maka penyelesaian uang pengganti agar ditindaklanjuti dengan cara Litigasi yaitu dengan melakukan gugatan secara perdata terhadap Terpidana/eks terpidana/ahli waris. Selanjutnya dalam angka 9 masih dalam Bab yang sama peraturan ini dikatakan bahwa terhadap putusan Pengadilan yang telah berkekuatan hukum tetap dan Tergugat/ahli waris tidak mampu membayar maka Jaksa Pengacara Negara mengajukan permohonan kepada Pengadilan untuk menerbitkan Surat Ketetapan yang menyatakan bahwa eksekusi tidak dapat dilaksanakan karena Tergugat/ahli waris tidak mampu.

Sehubungan dengan efektifitas Jaksa Pengacara Negara dalam pemulihan keuangan Negara/Daerah sebagai akibat tindak pidana korupsi, berdasarkan hasil penelitian terhadap beberapa putusan perkara korupsi yang telah mempunyai kekuatan hukum tetap dan sudah diserahkan berkas perkaranya dari Seksi Tindak Pidana Khusus ke Seksi Perdata dan Tata Usaha Negara Kejaksaan Negeri Purwokerto untuk dilakukan penyelesaian pembayaran uang penggantinya, ternyata tidak semua putusan perkara tindak pidana korupsi yang telah mempunyai kekuatan hukum tetap para terpidananya atau ahli warisnya membayar uang pengganti sebagaimana yang telah diputuskan oleh Pengadilan walaupun Jaksa Pengacara Negara pada Kejaksaan Negeri Purwokerto sudah melalui upaya Non Litigasi dan Litigasi, dimana hanya ada beberapa putusan perkara tindak pidana korupsi yang pengembalian keuangan Negara/Daerah berhasil dilakukan oleh Jaksa Pengacara Negara melalui jalur Non Litigasi

Adapun pemulihan keuangan Negara/Daerah sebagai akibat 
1147 | Jurnal Idea Hukum

Vol. 4 No. 2 Oktober 2018

Magister Hukum Fakultas Hukum Universitas Jenderal Soedirman

tindak pidana korupsi yang

dilakukan secara Non Litigasi yang

berhasil dilakukan pembayaran

uang pengganti oleh Jaksa

Pengacara Negara terdapat dalam putusan :

1. Perkara Korupsi putusan

Nomor:

97/Pid.B/1998/PN.Pwt

tanggal 4 Juni 1998 atas nama Terpidana Parlan SP.

Bahwa perkara ini adalah perkara tindak pidana korupsi yang menggunakan instrumen Undang-Undang Nomor 3 Tahun 1971, yakni Terdakwa Parlan SP dijatuhi pidana tambahan berupa pembayaran uang pengganti sebesar Rp. 5.000.000,- (lima juta rupiah).

Bahwa Jaksa Pengacara Negara dalam upaya pemulihan keuangan Negara/daerah melalui pengembalian uang pengganti dalam perkara ini adalah dengan cara Non Litigasi yakni Terpidana mampu mengangsur sesuai dengan surat penyataannya setiap bulannya dan telah lunas walaupun lama jangka

waktunya.

2. Perkara Korupsi putusan Nomor:

185/Pid.B/2004/PN.Pwt tanggal 14 Desember 2005 atas nama Terpidana H.Toni Abidin bin H.Ismail. Bahwa perkara ini juga diselesaikan dan diputus dengan instrumen UndangUndang Nomor 3 Tahun 1971, yakni Terdakwa H.Toni Abidin bin H.Ismail dijatuhi pidana tambahan berupa pembayaran uang pengganti sebesar Rp. 31.503.000,- (tiga puluh satu juta lima ratus tiga ribu rupiah).

Bahwa Jaksa Pengacara Negara dalam upaya pemulihan keuangan Negara/Daerah melalui pengembalian uang pengganti dalam perkara ini adalah dengan cara Non Litigasi yakni Terpidana mampu mengangsur sesuai dengan surat penyataannya setiap bulannya dan telah lunas walaupun lama jangka waktunya. 
Sedangkan pemulihan terhadap kerugian keuangan Negara/Daerah yang dilakukan Jaksa Pengacara Negara pada Kejakasaan Negeri Purwokerto sebagai akibat tindak pidana korupsi yang dilakukan secara Litigasi dapat dilihat dalam putusan perkara:

1. Perkara korupsi putusan Nomor: 138/Pid.B/2000/Pn.Pwt tanggal 21 September 2000 atas nama Terpidana Darmono bin Sumaryo.

Bahwa dalam putusan perkara ini Terdakwa Darmono bin Sumaryo dijatuhi pidana tambahan berupa pembayaran Uang Pengganti sebesar Rp. 146.851.705,89 (seratus empat puluh enam juta delapan ratus lima puluh satu ribu tujuh ratus lima rupiah delapan puluh sembilan sen), dimana penyelesaian perkara ini menggunakan

instrumen UndangUndang Nomor 3 Tahun 1971 tentang Pemberantasan Tindak Pidana Korupsi.
Bahwa upaya yang

dilakukan Jaksa

Pengacara Negara pada

Kejaksaan Negeri

Purwokerto dalam

pemulihan keuangan

Negara/Daerah

terhadap perkara ini adalah dengan cara mengajukan gugatan perdata ke Pengadilan Negeri Purwokerto oleh karena Terpidana tidak mampu membayar Uang Pangganti dengan dibuktikan adanya Surat Keterangan dari Kepala Desa setempat dimana Terpidana bertempat tinggal dan setelah dilakukan pengecekan harta kekayaan oleh Tim/petugas maka penyelesaiannya adalah dengan cara Litigasi yakni Kepala Kejaksaan Negeri Purwokerto menerbitkan Surat Kuasa Khusus (SKK) kepada Jaksa Pengacara Negara pada Kejaksaan Negeri Purwokerto yang ditunjuk untuk mengajukan gugatan perdata terhadap Terpidana, hal ini sesuai 
1149 | Jurnal Idea Hukum

Vol. 4 No. 2 Oktober 2018

Magister Hukum Fakultas Hukum Universitas Jenderal Soedirman

dengan SEMA Nomor 4

Tahun 1988 dimana

diatur tentang eksekusi

terhadap hukuman

pembayaran Uang

Pengganti (Pasal 34 sub

C Undang-Undang

Nomor 3 Tahun 1971)

yang pada poin 3 nya

menyebutkan bahwa

apabila dalam

pelaksanaan eksekusi

pembayaran Uang

Pengganti jumlah

barang-barang yang

dimiliki Terpidana tidak

mencukupi lagi, maka

kiranya harus diajukan

melalui gugatan perdata

di Pengadilan.

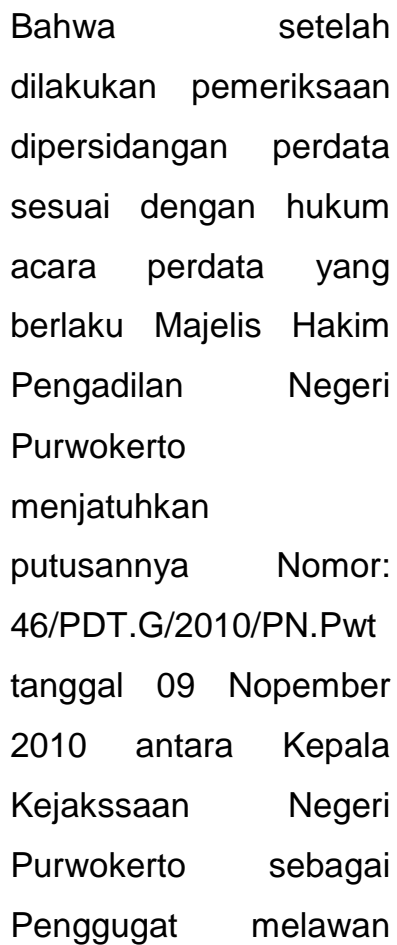

Darmono bin Sumaryo

sebagai

Tergugat,dimana dalam

amar

putusannya

meenyatakan:

1. Mengabulkan

Gugatan Penggugat untuk sebagian;

2. Menyatakan

Tergugat telah

melakukan

perbuatan melawan

hukum;

3. MenghukumTergugat untuk membayar uang pengganti sejumlah Rp.

146.851.705,89

(seratus empat puluh enam juta delapan ratus lima puluh satu ribu tujuh ratus lima rupiah delapan puluh sembilan sen) kepada Penggugat;

4. MenghukumTergugat untukmeembayar biata perkara dalam perkara ini yang hingga kini berjumlah Rp.206.000,- (dua ratus enam ribu rupiah);

Bahwa sekalipun Jaksa Pengacara Negara pada 


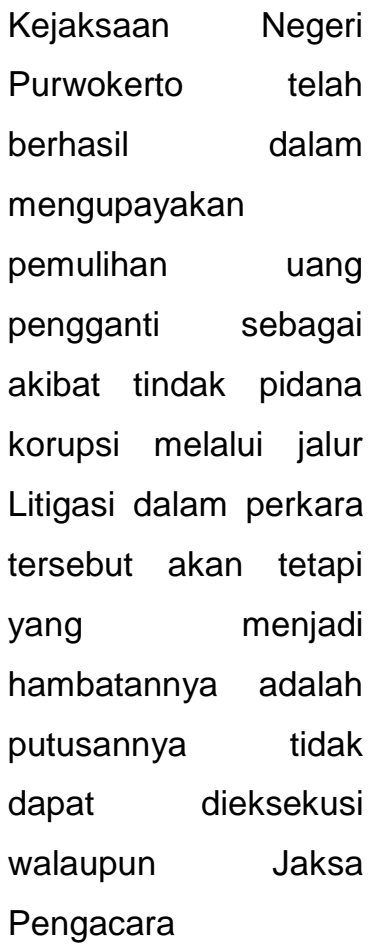

Negara/Penggugat

sudah melayangkan

surat kepada Ketua

Pengadilan Negeri

Purwokerto pada

tanggal 24 Juni 2011

untuk memohon agar

putusan tersebut

segera dieksekusi

namun hasilnya belum

ada karena sampai

saat ini Tergugat tetap

tidak mampu.

Bahwa sesuai dengan

Bab $V$ angka 9

Peraturan Jaksa

Agung Republik

Indonesia Nomor :

Per-020/A/JA/07/2014

tanggal 22 Juli 2014

tentang Petunjuk
Pelaksanaan

Penyelesaian Uang

Pengganti yang

diputus Pengadilan

berdasarkan Undang-

Undang Nomor 3

Tahun 1971 tentang

Pemberantasan

Tindak Pidana Korupsi

disebutkan bahwa

terhadap putusan

Pengadilan yang telah

berkekuatan hukum

tetap dan tergugat/ahli

waris tidak mampu

membayar maka

Jaksa Pangacara

Negara mengajukan

permohonan kepada

pengadilan untuk

menerbitkan Surat

Ketetapan yang

menyatakan bahwa

eksekusi tidak dapat

dilaksanakan karena

tergugat/ahli waris

tidak mampu.

2. Perkara Korupsi

Putusan Nomor:

90/Pid.B/2000/PN.Pwt

tanggal 28 September

2000 jo Putusan Nomor:

385/Pid/2000/PT.Smg

tanggal 22 Pebruari

2001 jo Putusan Nomor:

223K/Pid/2002 tanggal

11 Juli 2002 atas nama 
Sri Setyaningsih binti

Sudiharjo.

Bahwa dalam putusan perkara ini Terdakwa Sri

Setyaningsih binti

Sudiharjo dijatuhi

pidana tambahan

berupa pembayaran

Uang Pengganti

sebesar

Rp.

101.541.750,- (seratus satu juta lima ratus empat puluh satu ribu tujuh ratus lima puluh rupiah), dimana penyelesaian perkara ini menggunakan

instrumen UndangUndang Nomor 3 Tahun 1971 tentang

Pemberantasan Tindak Pidana Korupsi.

Bahwa pemulihan keuangan

Negara/Daerah yang harus dilakukan

Terpidana melalui Jaksa Pengacara Negara pada Kejaksaan NegeriPurwokerto terhadap putusan perkara diatas adalah dengan cara Litigasi karena Terpidana tidak mampu dengan menunjukan Surat Keterangan Tidak
Mampu dari Kelurahan Bancarkembar Nomor: 475/2339/2006 tanggal 14 Septeember 2009. Oleh karena Terpidana tidak mampu membayar Uang Pangganti yang dibuktikan dengan Surat Keterangan dari Kepala Desa setempat maka penyelesaiannya adalah dengan cara Litigasi yakni Kepala Kejaksaan Negeri Purwokerto menerbitkan Surat Kuasa Khusus (SKK) kepada Jaksa Pengacara Negara pada Kejaksaan Negeri Purwokerto yang ditunjuk untuk mengajukan gugatan perdata terhadap Terpidana, hal ini sesuai dengan SEMA Nomor 4 Tahun 1988 dimana diatur tentang eksekusi terhadap hukuman pembayaran Uang Pengganti (Pasal 34 sub c Undang-Undang Nomor 3 Tahun 1971) yang pada poin 3 nya menyebutkan bahwa apabila dalam pelaksanaan eksekusi 


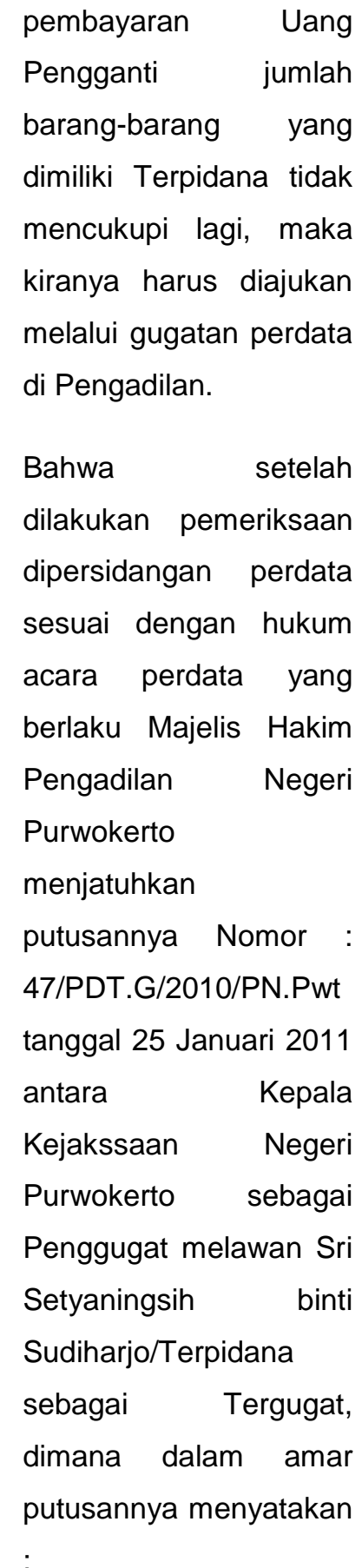

1. Mengabulkan

Gugatan Penggugat untuk sebagian ;

2. Menyatakan

Tergugat telah melakukan perbuatan melawan

hukum ;

3. Menghukum

Tergugat untuk membayar uang pengganti sejumlah Rp. 141.541.750,(seratus empat puluh satu juta lima ratus empat puluh satu ribu tujuh ratus lima puluh rupiah) kepada Penggugat ;

4. MenghukumTergugat untuk membayar biaya perkara dalam perkara ini yang hingga kini berjumlah Rp.481.000,-(dua ratus enam ribu rupiah) ;

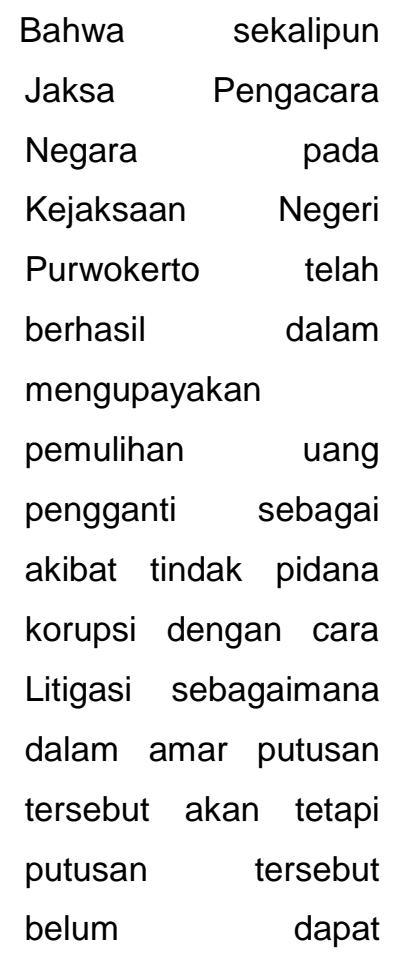


1153 | Jurnal Idea Hukum

Vol. 4 No. 2 Oktober 2018

Magister Hukum Fakultas Hukum Universitas Jenderal Soedirman

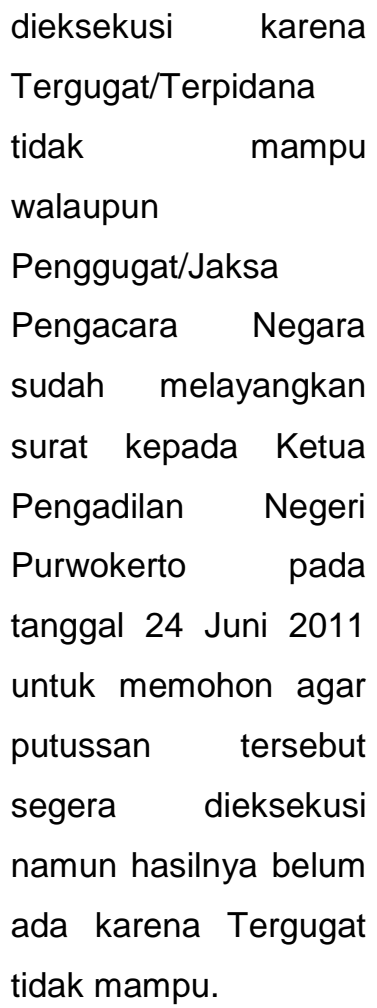

Bahwa sesuai dengan

Dalam Bab V angka 9

Peraturan Jaksa

Agung Republik

Indonesia Nomor :

Per-020/A/JA/07/2014

tanggal 22 Juli 2014

tentang Petunjuk

Pelaksanaan

Penyelesaian Uang

Pengganti yang

diputus Pengadilan

berdasarkan Undang-

Undang Nomor 3

Tahun 1971 tentang

Pemberantasan

Tindak Pidana Korupsi

disebutkan bahwa

terhadap putusan
Pengadilan yang telah

berkekuatan hukum

tetap dan tergugat/ahli

waris tidak mampu

membayar maka

Jaksa Pangacara

Negara mengajukan

permohonan kepada

pengadilan untuk

menerbitkan Surat

Ketetapan yang

menyatakan bahwa

eksekusi tidak dapat

dilaksanakan karena

tergugat/ahli waris

tidak mampu.

\section{Sedangkan}

pemulihan terhadap

kerugian keuangan

Negara/Daerah yang

dilakukan Jaksa Pengacara

Negara pada Kejakasaan

Negeri Purwokerto sebagai

akibat tindak pidana

korupsi karena

Terpidananya meninggal dapat dilihat dalam putusan perkara :

1. Perkara Korupsi putusan Nomor :

118/Pid.B/2007/PN.Pwt

tanggal 29-10-2007 jo putusan Nomor : 344/Pid/2007/PT.Smg tangal 24-01-2008 atas 


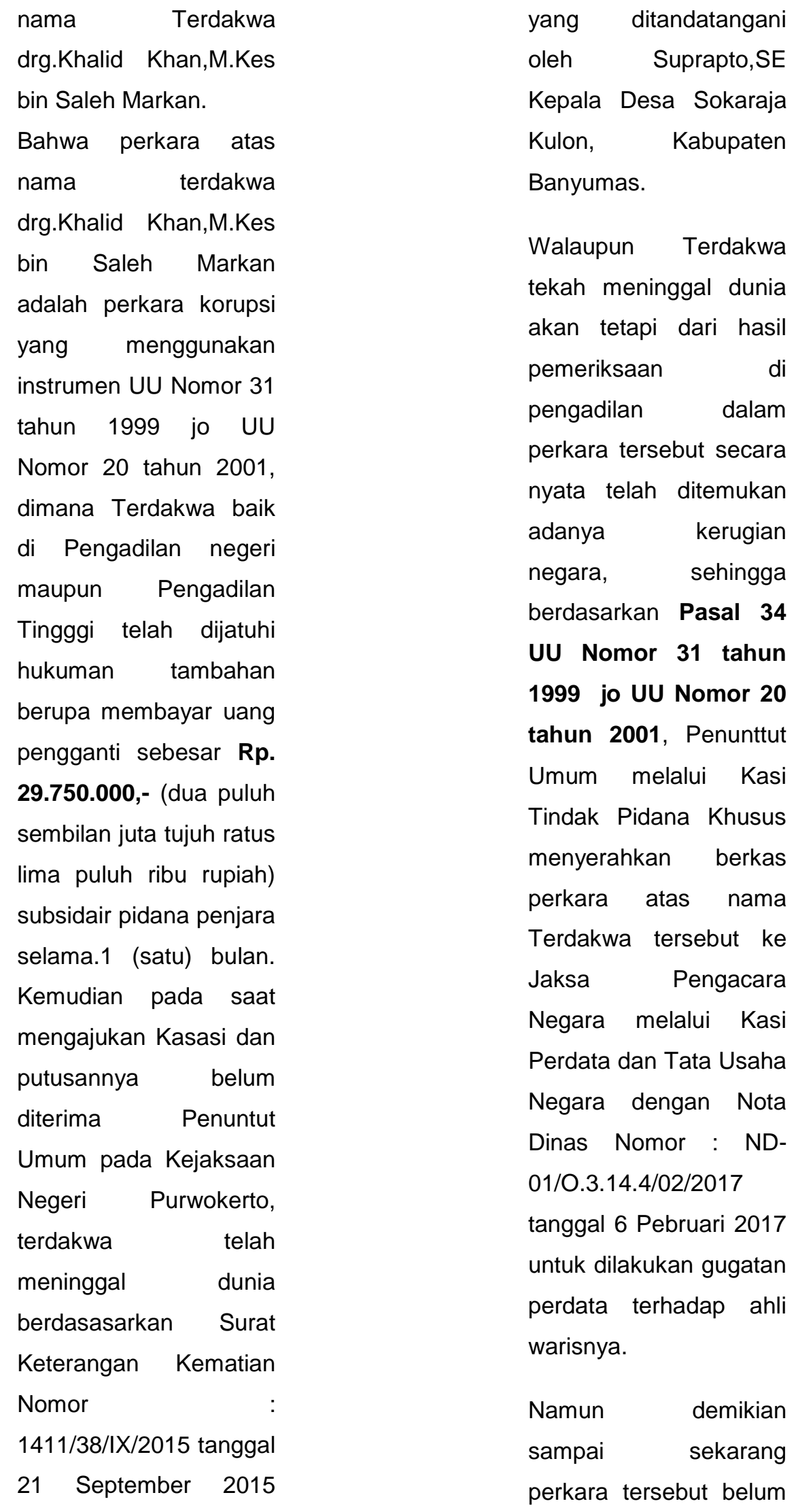


1155 | Jurnal Idea Hukum

Vol. 4 No. 2 Oktober 2018

Magister Hukum Fakultas Hukum Universitas Jenderal Soedirman

$$
\begin{array}{lr}
\text { diajukan } & \text { gugatan } \\
\text { perdata oleh } & \text { Jaksa } \\
\text { Pengacara Negara pada } & \\
\text { Kejaksaan } & \text { Negeri } \\
\text { Purwokerto. } &
\end{array}
$$

2. Perkara korupsi putusan Nomor

112/Pid.B/2004/PN.Pwt tanggal 4-11-2004 jo putusan Nomor : 250/Pidd/2004/PT.Smg tanggal 4-1-2005 jo putussan Nomor :813K/Pid/2005 tanggal 24-6-2006 atas nama Terdakwa Wiyono Hadi Sumarto bin Rasum.

Dalam perkara ini Terdakwa Wiyono Hadi Sumarto bin Rasum dijatuhi pidana tambahaan berupa pembayaran uang pengganti sebesar

Rp.312.519,018,-- (tiga ratus dua belas juta lima ratus sembilan belas ribu delapan belas rupiah) dan Terpidana tersebut telah meninggal dunia bardasarkan Surat Keterangan Kematian Nomor 474.3/357/22011 tanggal 30 Juli 2008

$$
\begin{aligned}
& \text { yang ditandatangani } \\
& \text { oleh Kepala Kelurahan } \\
& \text { Gumelar sebelum } \\
& \text { membayar uang } \\
& \text { pengganti dan setelah } \\
& \text { berkas perkaranya } \\
& \text { diserahkan ke Seksi } \\
& \text { Perdata dan Tata Usaha } \\
& \text { Negara } \\
& \text { Kejaksaan } \\
& \text { Negeri Purwokerto }
\end{aligned}
$$

\section{Sehingga}

berdasarkan hasil penelitian terhadap beberapa putusan Pengadilan yang telah memperolah kekuatan hukum tetap dalam perkara tindak pidana korupsi sebagaimana tersebut diatas, Jaksa Pengacara Negara pada Kejaksaan Negeri Purwokerto dalam melakukan pemulihan keuangan

Negara/Daerah sebagai akibat tindak pidana korupsi tidak efektif apabila penyelesaiannya menggunakan UU Nomor 3 tahun 1971 


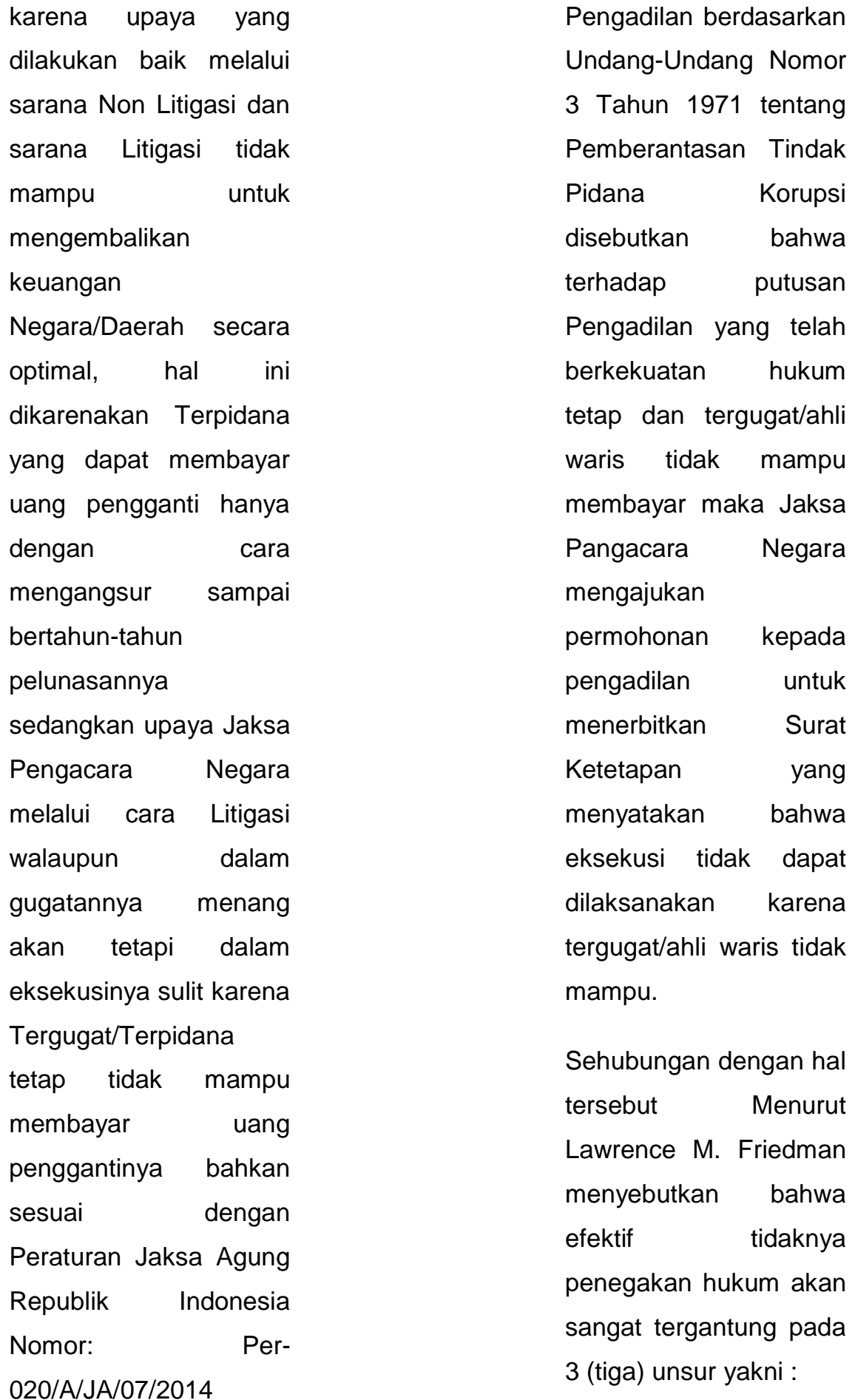

tanggal 22 Juli 2014

Bab IV angka 9 tentang

Petunjuk Pelaksanaan

1. Substansi hukum/legal substance (peraturan hukum itu sendiri).

Penyelesaian Uang

Pengganti yang diputus

2. Struktur hukum/legal structure (aparat penegak hukum) dan 
1157 | Jurnal Idea Hukum

Vol. 4 No. 2 Oktober 2018

Magister Hukum Fakultas Hukum Universitas Jenderal Soedirman

3. Budaya hukum /legal culture (masyarakatnya).

Ad.1. Substansi hukum (legal subtance)

Bahwa dalam perkara tindak pidana korupsi yang penyelesaiannya menggunakan UU Nomor 3 tahun 1971 dalam hal pidana tambahan berupa pembayaran uang pengganti tidak ada hukuman penggantinya artinya apabila Terdakwa dijatuhi pidana tambahan berupa uang pengganti maka harus membayarnya sebagai akibat tindak pidana korupsi yang dilakukannya (vide Pasal 34 huruf c UU Nomor3 Tahun 1971) dan apabila tidak mampu maka Jaksa Pengacara Negara akan melakukan penagihan baik secara Non Litigasi maupun Litigasi.

Bahwa dilihat dari segi aturan hukumnya (substansi hukumnya) memang pidana tambahan berupa uang pengganti dalam UU Nomor 3 Tahun 1971 sebagaimana yang tercantum dalam Pasal 34 huruf $c$ bersifat wajib dan tidak boleh tidak. Akan tetapi dalam faktanya bedasarkan beberapa putusan pekara tindak pidana korupsi yan telah mempunyai kekuatan hukum tetap eksekusi pembayaran uang pengganti sulit dilaksanakan oleh
Jaksa karena Terpidana sudah tidak mampu dan tidak mempunyai harta kekayaan lagi dan oleh karenanya penyelesaiannya mengunakan instrumen Jaksa Pengacara Negara melalui sarana Litigasi dan Non Litigasi, dan cara inipun kurang berhasil mengingat tidak semua pidana tambahan berupa pembayaran uang pengganti bisa diselesaikan.

Ad.2.Struktur hukum (Legal structure)

Bahwa efektifitas berlakunya hukum juga ditentukan oleh faktor aparat peengak hukumnya itu sendiri. Jaksa Pengacara Negara sesuai dengan Pasal 30 ayat (2) UU Nomor 16 Tahun 2004 bisa bertindak di dalam dan diluar Pangadilan untuk mewakili pemerintah dan negara, baik BUMN/BUMD, namun berdasarkan penelitian di Kejaksaan Negeri Purwokerto tidak semua berkas perkara yang penyelesaian pembayaran uang penggganti yang diserahkan ke Jaksa Pengacara Negara yang Terpidananya sudah tidak mampu lagi serta tidak mempunyai harta kekayaan dilimpahkan atau diselesaikan dengan Litigasi yakni dengan mengajukan gugatan perdata ke pengadilan mengingat tidak 


tersedianya dana secara maksimal
bagi Jaksa Pengacara Negara
untuk mengajukan gugatan
tersebut sehingga hal ini juga
menjadi kendala penyelesaian atau
pemulihan
Negara/daerah sebagai akibat
tindak pidana korupsi,
sebagaimana yang dikatakan Kasi
Perdata dan Tata Usaha Negara
pada Kejaksaan Negeri

Purwokerto, yakni:

bahwa ada bebarapa berkas perkara memang belum sempat diajukan gugatan perdata terhadap ahli warisnya mengingat bahwa dalam penyelesaian Uang Pengganti melalui jalur Litigasi Kejaksaan tidak memiliki anggaran atau biaya untuk mengajukan gugatan perdata sehingga penyelesaiannya tidak optimal ataupun tidak effektif dan hal demikian juga merupakan kendala atau hambatan Jaksa Pengacarta Negara dalam melakukan penyelesaian terhadap pemulihan keuangan negara/daerah sebagai akibat tindak pidana korupsi. ${ }^{141}$

Ad.3.Budaya hukum (Legal Cuktutre).

Salah satu faktor apakah hukum efektif atau tidak dalam pelaksanaaannya adalah tergantung pada faktor budaya hukum, yakni faktor sikap manusia terhadap hukum dan sistem hukum

${ }^{141}$.Wawancara dengan Kepala Seksi Perdata dan Tata Usaha Negara pada Kejaksaan Negeri Purwokerto, tangggal 5-122-2017. kepercayaan, nilai, pemikiran serta harapannya dan kesadaraannya. Kultur hukum adalah suasana pemikiran sosial dan kekuatan sosial yang menentukan bagaimana hukum digunakan, dihindari, atau disalahgunakan dan budaya hukum erat kaitannya dengan kesadaran hukum masyarakat.

Bahwa ternyata berdasarkan penelitian di Kejaksaan Negeri Purwokerto, berdasarkan data primier yang berasal dari nara sumber Kasi Perdata dan Tata Usaha Negara, Jaksa Pengacara Negara, Penasehat Hukum maupun Tepidana diperoleh fakta bahwa terpidana korupsi yang dijatuhi pidana dengan menggunakan UU Nomor 31 Tahun 1971 tentang Pemberantasan Tindak Pidana Korupsi pada saat dilakukan upaya penyelesaian atau pemulihan keuangan Negara/daerah sebagai akibat tindak pidana korupsi baik melalui Litigasi maupun Non Litigasi menyatakan tidak mampu, yang berarti bahwa kasadaran dari masyarakat ataupun Terpidana terhadap pidana tambahan berupa pembayaran uang pengganti yang dijatuhkan pengadilan kurang dan masa bodoh, mengingat akibat yang ditimbulkan apabila tidak membayar tidaklah begitu memberatkan bagi dirinya karena tidak ada sanksi yang tegas, sebagai contoh saja Jaksa 
1159 | Jurnal Idea Hukum

Vol. 4 No. 2 Oktober 2018

Magister Hukum Fakultas Hukum Universitas Jenderal Soedirman

Pengacara Negara yang telah mengajukan gugatan perdata terhadap Terpidana dan putusannya menyatakan menghukum

Tergugat/Terpidana untuk membayar uang pengganti akan tetapi walaupun Jaksa Pengacara Negara berhasil dalam gugatannya namun tidak dapat dieksekusi karena Terpidana tidak mampu. Sehingga faktor kultur atau budaya yakni kesadaran masyarakat akan pentingnya pemulihan uang pengganti sebagai akibat tindak pidana korupsi yang telah dilakukannya kurang sehingga penegakan hukum tidak efektif.

Berdasarkan hasil penelitian terhadap putusan pengadilan sebagaimana telah diuraikan diatas dalam perkara tindak pidana korupsi dimana dalam putusan tersebut Terpidana dijatuhi pidana tambahan berupa pembayaran uang pengganti, akan tetapi apabila ditinjau dari efektifitas Jaksa Pengacara Negara dalam upaya pemulihan keuangan Negara/Daerah sebagai akibat tindak pidana korupsi di Kejaksaan Negeri Purwokerto, maka hal tersebut dapat dikatakan tidak efektif apabila instrumen yang dipergunakan adalah UU Nomor 3 tahun 1971 tentang Pemberantasan Tindak Pidana Korupsi dibandingkan penyelesaiannya dengan UU No.31 tahun 1999 jo UU No.20 tahun 2001 tentang Perubahan dan Penambahan atas UU No.31 tahun 1999 tentang Pemberantasan Tindak Pidana Korupsi.

3. Hambatan-hambatan yang dialami Jaksa Pengacara Negara dalam Upaya pemulihan keuangan Negara/Daerah sebagai akaibat Tindak Pidana Korupsi di Kejaksaan Negeri Purwokerto.

Sesuai dengan UndangUndang Nomor 16 Tahun 2004 tentang Kejaksaan Republik Indonesia dalam Passal 30 ayat (2) disebutkan bahwa di bidang Perdata ddan Tata Usaha Negara, Kejakssaan dengan Kuasa Khusus dapat bertindak baik di ddalam maupun di luar pengadilan untuk dan atas nama Negara atau Pemerintah, maka Jaksa dapat bertindak selaku Jaksa Pengacara Negara (JPN). Sebagai lembaga yang mewakili pemerintah atau Negara maka Jaksa Pengacara Negara dtuntut untuk bekerja secara maksimal bilamana mendapatkan amanah untuk mewakili pemerintah atau negara baik didalam maupun diluar Pengadilan khususnya dalam hal pemulihan keuangan Negara/Daerah sebagai akibat 
tindak pidana korupsi yakni dalam rangka untuk mencapai tujuannya yakni mempercepat pengembalian kerugian keuangan Negara/Daerah sebagai akibat tindak pidana korupsi. Narasumber mengatakan bahwa hambatan-hambatan Jaksa Pengacara Negara dalam melakukan pemulihan keuangan Negara/Daerah berupa pengembalian atau pembayaran uang pengganti dari Terpidana sebagai akibat tindak pidana korupsi adalah sebagai berikut:

1. Bahwa dalam perkara tindak pidana korupsi, baik yang penyelesaiannya menggunakan UU Nomor 3 Tahun 1971 maupun dengan UU Nomor 31 Tahun 1999 jo UU Nomor 20 tahun 2001, apabila Terdakwa terbukti dinyatakan bersalah, ada kewajiban bagi Terdakwa untuk membayar uang pengganti hanya saja apabila penyelesaiannya menggunakan UU Nomor 3 Tahun 1971, maka Terdakwa tidak bisa mengganti dengan pidana kurungan/subsidair sehingga pemerintah melalui Jaksa Pengacara Negara berkewajiban untuk menagihnya baik melalui Litigasi maupun Non Litigasi. Yang menjadi kendala adalah apabila setelah ditelusuri ternyata Terdakwa tidak mempunyai harta kekayaan lagi yang dapat untuk menutup atau melunasi uang pengganti sehingga mau tida mau harus melalui Litigasi dan cara inipun nantinya akan menghambat eksekusinya karena Terpidana sudah tidak mempunyai harta kekayaan sehingga sekalipun Jaksa Pengacara Negara menang dalam gugataannya akan tetapi tidak bisa dieksusi. Berbeda dengan penyelesainnya menggunakan UU Nomor 31 Tahun 1999 jo UU Nomor 20 Tahun 2001 dimana apabila Terdakwa tidak mampu meembayar uang pengganti maka dapat diganti dengan hukuman subsidairnya.

2. Bahwa hambatan lainnya adalah apabila Terpidana sudah pindah alamat dan tidak diketahui keberadaannya sehingga akan menyulitkan Jaksa Pengacara Negara untuk 
1161 | Jurnal Idea Hukum

Vol. 4 No. 2 Oktober 2018

Magister Hukum Fakultas Hukum Universitas Jenderal Soedirman

memanggilnya sehubungan

dengan kewajibannya

untuk membayar uang

pengganti.

3. Kurangnya kesadaran

masyarakat untuk

memberitahukan tentang

adanya tindak pidana

korupsi yang terjadi

diwilayah lingkungannya

serta kurangnya informasi

terhadap

keberadaan/kepemilikan

harta benda yang dimiliki

Terpidana.

4. Bahwa

kurangnya

penguasaan ilmu hukum

perdata bagi Jaksa

Pengacara Negara, karena

hal ini adalah merupakan

ilmu baru yang selama ini

biasanya Jaksa hanya

berkutat pada hukum

pidana sementara Jaksa

Pangacara

Negara

meninggalkan hal-hal yang

sifatnya pidana dan

menggeluti dengan hal-hal yang sifatnya keperdataan.

5. Tidak adanya upaya paksa dalam hal Jaksa Pengacara Negara melakukan pemulihan keuangan Negara/Daerah sebagai akibat tindak pidana korupsi apabila Terdakwa setekah dipangil beberapa kali tidak memenuhi kewajibannya untuk membayar uang pengganti sesuai dengan amar putusannya.

E.

\section{E. Penutup.}

A. Simpulan.

Berdasarkan uraian di atas dalam pembahasan terhadap hasil penelitian dapat disimpulkan sebagai berikut:

1. Efektifitas Jaksa Pengacara Negara dalam upaya pemulihan keuangan negara/daerah sebagai akibat tindak pidana korupsi di Kejaksaan Negeri Purwokerto dapat diuraikan sebagai berikut :

a. Upaya pemulihan keuangan negara/daerah sebagai akibat tindak pidana korupsi yang diputus berdasarkan UU Nomor 3 tahun 1971 dapat dikatakan tidak efektif karena upaya yang dilakukan Jaksa Pengacara Negara dengan cara Non Litigasi dan Litigasi tidak mampu untuk mengembalikan keuangan negara/daerah secara optimal.

b. Sedangkan upaya pemuliham keuangan negara/daerah perkara korupsi 
yang diputus berdasarkan UU

No.31 tahun 1999 jo UUNo.20

tahun 2001 dapat dikatakan

efektif karena Jaksa

Pengacara Negara tidak perlu melakukan upaya dengan cara Non Litigasi maupun Litigasi mengingat dalam UU No.31 tahun 1999 jo UU No.20 tahun 2001 apabila Terpidana tidak dapat membayar uang pengganti dapat diganti dengan pidana kurungan kecuali apabila Terdakwanya meningal dunia pada saat Penyidikan atau Penuntutan/pemeriksaan di Pengadilan serta sudah diketahui telah ada kerugian keuangan negaranya maka Jaksa Pengacara Negara menyelesaikan dengan jalur Litigasi.

2. Hambatan-hambatan yang dialami Jaksa Pengacara Negara dalam upaya pemulihan keuangan negara/daerah sebagai akibat tindak pidana korupsi di Kejaksaan Negeri Purwokerto, yakni meliputi :

a. Apabila penyelesaian pemulihan keuangan negara/daerah menggunakan UU No.3 tahun 1971 tidak optimal karena penyelesaiannya secara Non Litigasi hanya dengan cara mengangsur sedangkan dengan Litigasi sekalipun Jaksa Pengacara

Negara menang dalam gugatannya akan tetapi Terpidana tetap tidak mampu membayarnya sehungga tidak bisa dieksekusi karena secara materiil sudah tidak mempunyai harta kekayaannya lagi.

b. Ada beberapa kondisi lain yang menghambat diantaranya : tempat tingal Terpidana yang tidak diktahui secara pasti sehingga menyulitkan Jaksa Pengacara Negara dalam melakukan upaya pemulihan keuangan negara/daerah baik secara Non Litigasi maupun Litigasi serta kurang kesadaran masyarakat untuk melaporkan adanya tindak pidana korupsi dilingkungannya serta tidak adanya kesadaran masyarakat untuk melaporkan harta benda yang dimiliki Terdakwa/Terpidana yang merupakan hasil dari tindak piddana korupsi.

B. Saran.

Dalam upaya untuk lebih mengefektifkan Jaksa Pengacara Negara dalam upaya pemulihan keuangan negara/daerah sebagai akibat tindak pidana korupsi di Kejaksaan Negeri Purwokerto, perlu: 
1163 | Jurnal Idea Hukum

Vol. 4 No. 2 Oktober 2018

Magister Hukum Fakultas Hukum Universitas Jenderal Soedirman

1. Ditingkatkan

profesionalisme sumber daya manusia yang telah ada karena Jaksa Pengacara Negara merupakan hal baru yang biasanya jajaran Kejaksaan hanya bergulat pada segi pidana saja namun pada Jaksa Pengacara Negara harus mempunayai wawasan yang luas dan profesionalisme khusunya dalam bidang keperdataaan.

2. Ditingkatkan kesadaran hukum masyarakat dalam mendukung dan berperan dalam penegakan pemberantasan korupsi termasuk memberikan informasi secara objektif terhadap harta benda yang diperoleh Terpidana dari hasil korupsinya.

\section{DAFTAR PUSTAKA}

Amrin,Hanafi dan Mahrus Ali, 2015. Sistem Pertanggungjawaban Pidana Perkembangan dan Penerapan, PT.Raja Grafika Persada, Jakarta.

Effendi,Marwan, 2012. Sistem Peradilan Pidana Tinjauan Terhadap Beberapa Perkembangan Hukum Pidana, Referensi.

http://rubrik

okezone.com/read/10538/beranta $s$ korupsi dengan strategi follow the money.

Hamzah,Andi, 2015. Pemberantasan Korupsi melalui Hukum Pidana Nasional dan Internasional, PT. Raja Grafika Persada, Jakrata.

Hartanti,Evi, 2005. Tindak Pidana Korupsi, Sinar Grafika, Jakarta.

Komisi Pemberantasan Tindak Pidana Korupsi, 2006. Memahami Untuk Membasmi Buku Saku Untuk Memahami Tindak Pidana Korupsi, Jakarta.

Keitjer,Schffmeister N. dan E.PH.Sitaurus, 2004. Hukum Pidana Kumpulan Bahan Penataran Hukum Pidana Dalam Rangka Kerjasama Hukum Indonesia-Belanda, Cet.ke-3, Liberty, Yogyakarta.

Lopa,Baharudin, 1997. Masalah Korupsi dan Pemecahannya, Kipas Putih Aksara, Jakarta.

M.Friedman,Lawrence, 2009, Sistem Hukum Perspektif IImu Sosial (The Legal System A Social Science Perspective), Nusa Media, Bandung.

Moeljatno, 1955. Perbuatan Pidana dan Pertanggungan Jawab Pidana, Universitas Gadjah Mada, Yogyakarta.

Pramono,Widyo, 2015. Implikasi Satgassus P3TPK Kejaksaan Dalam Pemberantasan Korupsi, Majalah Prosekutor, edisi MaretApril 2015.

Prins,Darwin, 2002. Pemberantasan Tindak Pidana Koupsi, Citra Aditya Bakti, Bandung.

Projodikoro,Wirjono, 2003. Asas-asas Hukum Pidana di Indonesia, Edisi ke-3, Refika Aditama, Bandung.

Ramelan, 2001. Undang-Undang Pemberantasan Tindak Pidana Korupsi, Kapita Selekta Tindak 
Pidana Korupsi, Puslitbang, Diklat MA RI, Jakarta.

Soemitro,Ronny Hanitijo, 1992. Metodologi Penelitian Hukum, Ghalia Indonesia, Jakarta.

Sunggono,Bambang, 2006. Metode Penelitian Hukum, Penerbit PT.Raja Grafindo Persada, Jakarta.

Soekanto,Soerjono,1984. Pengantar Penelitian Hukum, Penerbit Universitas Indonesia.

Sosiologi Hukum, Alumni

Bandung.

Susanto IS, 1992. Pemahaman Kritis Terhadap Realita Sosial (Majalah Hukum No.9.

Sunaryo,Sidik, 2005, Kapita Selekta Peradilan Pidana, Universitas Muhammadiyah Malang.

Sapardjaja,Komariah Emong, 2002. Ajaran Sifat Melawan Hukum Materiel Dalam Hukum Pidana Indonesia, Studi Kasus Penerapan dan Perkembangannya Dalam Yurisprudensi, Alumni Bandung.

Siahaan,Monang, 2016. Pembaharuan Hukum Pidana Indonesia, Penerbit PT.Grasindo, Jakarta.

Suradi, 2006. Korupsi Dalam Sektor Pemerintahan dan Swasta,Penerbit Gava Media, Yogyakarta.

Sugandhi,R., 1981. Kitab UndangUndang Hukum Pidana (KUHP) Dengan Penjelasannya, Usaha Nasional,Surabaya.

Waluyo, ,Bambang, 2016, Penegakan Hukum di Indonesia, Penerbit PT.Sinar Grafika 